\title{
一般 55
}

\section{痛風高尿酸血症における耐糖能異常の検討}

目的

高尿酸血症の発症には過食や肥満などの生活習 慣が関与しており，当院を受診した患者のうち BMI 25 以上は $51.2 \% ， 30$ 以上は $11.7 \%$ と一般成人 男子のそれぞれ $30 \%$ と $4 \%$ をはるかに上回る。 そ こで痛風・高尿酸血症患者における耐糖能異常に ついて検討した。

\section{対象}

当院を受診した男性痛風・高尿酸血症患者 901 名, 平均年齢 45 歳 \pm 11 歳を対象とした。

\section{結 果}

BMI は平均 $25.6 \pm 5.8$ で年齢と共に有意な低下 が認められた。一方 HbA1cは年齢と共に有意に 増加し $(\mathrm{r}=0.242, \mathrm{p}<0.0001)$, 年代別では 30 歳未満 が $5.3 \pm 0.2 \% ， 30$ 歳台が $5.4 \pm 0.4 \% ， 40$ 歳台が $5.5 \pm$ $0.5 \%, 50$ 歳台が $5.6 \pm 0.4 \%, 60$ 歳以上が $5.7 \pm 0.5 \%$ と 10 歳毎に $0.1 \%$ の増加が認められ $(\mathrm{p}<0.0001)$, 空腹時血糖值も同様に年齢と共に有意に増加し $(\mathrm{r}=0.391, \mathrm{p}<0.0001), 30$ 歳未満が $90 \pm 8 \mathrm{mg} / \mathrm{dL}, 30$ 歳台が $89 \pm 8 \mathrm{mg} / \mathrm{dL} ， 40$ 歳台が $91 \pm 7 \mathrm{mg} / \mathrm{dL} ， 50$ 歳 台が $98 \pm 10 \mathrm{mg} / \mathrm{dL}, 60$ 歳以上が $97 \pm 6 \mathrm{mg} / \mathrm{dL}$ と増

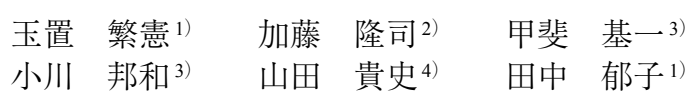

加が認められ $(\mathrm{p}<0.0001)$, 特に50歳以上での増加 が明らかであった。インスリン抵抗性の指標であ る HOMA-Rは加齢に伴う有意な変動はなく $(\mathrm{r}=-$ $0.058, \mathrm{p}=0.33)$, 年代別では 30 歳未満が $1.8 \pm 1.0$, 30 歳台が $1.4 \pm 0.9,40$ 歳台が $1.5 \pm 0.8,50$ 歳台が 1.5 $\pm 0.8,60$ 歳以上が $1.2 \pm 0.7$ であった $(\mathrm{p}=0.303)$. 一 方インスリン分泌能の指標である HOMA- $\beta$ は年 齢と共に有意な低下が認められ $(\mathrm{r}=-0.351$, $\mathrm{p}<0.0001)$, 年代別では30歳未満が $119 \pm 54,30$ 歳 台が $93 \pm 53,40$ 歳台が $86 \pm 42,50$ 歳台が $64 \pm 32$, 60 歳以上が $55 \pm 22$ と低下した $(\mathrm{p}<0.0001)$. 対象患 者数を年齢で 3 分割し HOMA- $\beta$ と BMIを検討す ると 20 歳から 40 歳, 41 歳から 49 歳はそれぞれ有 意な正の相関を示したが50歳以上では相関を認 めなかった。一方, HOMA-Rは3つの年代全てで BMI と正の相関を示した.

\section{考察}

痛風・高尿酸血症患者における耐糖能異常は, 加齢に伴うインスリン分泌能の低下が原因と考え られた．肥満に伴うインスリン分泌の増加が失わ れ，血糖值の上昇が認められる50歳台以前での積 極的な栄養指導などの介入が重要と考えられた。
1）医療法人IRO名古屋膠原病リウマチ痛風クリニック

2）国立長寿医療研究センター放射線診療部

3）医療法人 IRO三重膠原病リウマチ痛風クリニック

4）中部大学応用生物学部
Shigenori Tamaoki, Ikuko Tanaka

Takashi Kato

Motokazu Kai, Kunikazu Ogawa

Takashi Yamada 